\title{
Lyon's Wagnerian Diva: Louise Janssen (1863-1938)
}

\author{
Katharine Ellis \\ Accepted for Cambridge Opera Journal 30/1 (March 2018) on 5 April 2018
}

\begin{abstract}
It seems historiographically implausible to ascribe the reputation of fin-de-siècle Lyon as France's Bayreuth to the impact of a single middle-ranking soprano, but the Danish singer Louise Janssen's long-term presence, galvanic musical influence, and box-office value suggest precisely that conclusion. Part of the explanation lies with the diva-worship of her supporters ('Janssenistes'), who curated her image both during her career and in her retirement to create an adopted musical heroine whose memory remains guarded by Lyon council policy. That image, selectively constructed from among her Wagner roles, also typecast her as a singer who had much in common with Symbolist art - a potential Mélisande that Lyon never saw. This essay brings together archival and press materials to explain how a foreign-born singer's agency and mythification contributed to a double French naturalisation - her own, and that of Wagner(ism).
\end{abstract}

A gravestone in the Croix-Rousse cemetery in northern Lyon sums up what the Danish soprano Louise Janssen meant to the city's opera-goers when it was erected in 1943, half a century after her heyday: 'Elsa 1891; Elisabeth 1892; Sieglinde 1894; Eva 1896; Yseult 1900; Brunehilde 1903.' She was by all accounts an unusual singer within the French operatic system. She was originally employed as the dark-voiced dramatic soprano known in France as a 'Falcon', but she seems rarely to have sung the old French répertoire, stretching back to Meyerbeer, for which her official voice-type was generally required; indeed by the 
end of her career she was officially listed as a 'Chanteuse wagnérienne'. ${ }^{1}$ She worked within a national system that produced high singer turnover in each French theatre, and had a career also involving appearances in London, Monte-Carlo, Paris, and major American cities. Nevertheless, she appeared as a quasi-regular member of the Lyon company at the GrandThêâtre over a period of seventeen years. Indeed, despite being audibly non-native with her Danish-accented singing, she became the resident star of a city vying to be recognized as second only to Paris in operatic terms, and intensely proud of its contribution to French Wagnerism. It seems historiographically implausible to ascribe to the impact of a single middle-ranking soprano the reputation of fin-de-siècle Lyon as France's Bayreuth, and yet Janssen's long-term presence, uniquely galvanic influence, and box-office value suggest precisely that conclusion. She and the success of Lyonnais Wagnerism became inseparable.

Crucially, the afterburn of her career and the memories it evoked are as important as the career itself: continued local fandom turns her into a living legend - a process helped by her residence in Lyon after her almost casual retirement from the municipal stage in 1907, her work as a concert soloist until 1913, and her repute as a singing teacher. ${ }^{2}$ She also emerges as a decentralizing figure who in the early 1890s prefigured more familiar singers of Wagnerian roles (such as the Swiss Lucienne Bréval and the Russian-Canadian Félia Litvinne), and whose continuing devotion to Lyon meant that throughout the period, France's first and second cities were each a beacon of operatic Wagnerism. As part of a longstanding tension between a centralist and domineering Paris and a subordinate regional city, Lyon's Wagnerian credentials were of crucial importance in challenging Parisian cultural pre-

\footnotetext{
${ }^{1}$ Arch. Mun. Lyon, 88 WP 028, Folder 69. Grand-Théâtre report on the 1906-1907 season.

${ }^{2}$ See Le Salut public, 27 April 1927, 2 (reporting on the celebrations when she was made an Officier de l'Instruction Publique).
} 
eminence. Lyon, after all, was the city to which Cosima Wagner awarded permission for the first French Meistersinger (1896, at which Janssen sang Eva), and which staged the first complete French Ring cycle. Not for nothing did Lyonnais of this period call their GrandThéâtre their ‘Opéra'. Finally, Janssen's game-changing capacity in Lyon is suggested by press commentary to the effect that after a decade or so, the new aesthetic she instituted began to have negative consequences, including the petrification of musical taste occasioned by audience nostalgia for a golden era in which Janssen and Lyon's preeminent Wagnerism went hand in hand. No other singer - not even the rather better-paid Marius Verdier, who was Janssen's stage partner from 1903 - provoked comparable expressions of reverence or loyalty, or was accorded such significance in Lyon's operatic history. ${ }^{3}$ In short, in her adopted city, Janssen effected a double French naturalization - her own, and that of Wagner in France: it is a measure of official recognition of both naturalizations that in 2005, Lyon's city council voted to pay in perpetuity for the upkeep of her grave. ${ }^{4}$

In this article I explore what Janssen brought to the Lyon stage to create the aura that defined her as a specifically Wagnerian soprano even though her range extended much wider - from Gluck, via Mozart, to Verdi, D’Indy, Massenet, and Puccini. The Janssen myth was a selective one, and since much of its import resides in selectivity, I chart its construction across five decades of commentary from the singer's fan club of 'Janssenistes' (and their opponents), while also suggesting that her allure rested on largely unspoken cultural links with pre-Raphaelite and Symbolist art that rendered her less an archetypal international

\footnotetext{
${ }^{3}$ In 1904-05 Marius Verdier earned 40,000 francs over 6 months (54 performances equating to a little over 740 francs per performance), to Janssen's 15,000 (30 performances at 500 or exceptionally 600 francs each). Arch. Mun. Lyon 89 WP 014.

${ }^{4}$ Lyon Conseil municipal, meeting of 12 December 2005, reference no. 6012.

http://www.static.lyon.fr/pdf/200512/delib/20056012.pdf (accessed 17 January 2016).
} 
Wagnerian soprano than a rare incarnation of the principles underlying painterly expressions of French Wagnerism. As is so often the case with female performers, very little comes from Janssen herself. A single article she published in Léon Vallas's Revue musicale de Lyon outlines her philosophy of singing, and in very general terms $;{ }^{5}$ scant correspondence survives. Also lacking are first-hand accounts of women's reactions to her performances and to the phenomenon she became once her stage career had ended. With all the risks of one-sidedness it entails, the analysis that follows is accordingly dependent for its evidence on the voices of men alone, many of them engaged in blatant diva-construction. ${ }^{6}$ Indeed, there is more than a little of Michel Poizat or Wayne Koestenbaum's obsessive opera fans in the ecstatic and aestheticized reactions of Lyon's Janssenistes - though there is considerably less of Koestenbaum's 'diva' in what little we know of the singer's own conduct. ${ }^{7}$

\section{Janssen's career}

Louise Janssen was hired specifically to sing the first Lyon Lohengrin (26 February 1891). Her début, however, was in more traditional fare, as Gounod's Marguerite in a benefit performance the previous month. Unlike many other singers hired to perform in the rash of

${ }^{5}$ Louise Janssen, 'L’acteur lyrique’, La Revue musicale de Lyon, 9 April 1905, 292-3.

\footnotetext{
${ }^{6}$ Were the purple prose of her fans all we possessed, it would be difficult to provide anything approaching a grounded reading of Janssen's singing or acting. Luckily, as will become clear, it is possible to triangulate these expressions of fandom with two contrasting perspectives: first, reviews from detractors who identify similar traits but value them differently; and second with a 'revelation' testimony from Léon Vallas that points, once more, to the same characteristics and habits. In addition, photographic evidence - stylistically highly unusual for the period - offers further insight into her stage presence.

${ }^{7}$ Michel Poizat, The Angel's Cry: Beyond the Pleasure Principle in Opera, trans. Arthur Denner (Ithaca \& London, 1992); Wayne Koestenbaum, The Queen's Throat: Opera, Homosexuality and the Mystery of Desire (London, 1993).
} 
Lohengrin premieres in French cities in 1891, she seems to have had no previous professional experience singing Wagnerian roles and accordingly represented quite a risk on the part of the Grand-Théâtre's director Henri Poncet. ${ }^{8}$ Many aspects of her biography remain unclear. Claims of her Wagnerian competence and authority rest on her having trained in Graz with Amalie Materna, the Viennese soprano who created Brünnhilde and Kundry at Bayreuth, but the sources of this information - all anecdotal and all from Lyon - become problematic when one tries to establish possible dates. ${ }^{9}$ In terms of early formation, the Kutsch/Riemens dictionary of singers - which is inaccurate in several respects - mentions only vocal training in Copenhagen and cites no teachers. ${ }^{10}$ In France, however, she seems to have studied with Rosine Laborde. ${ }^{11}$ Yet there is no Wagnerian element here: Laborde was a specialist in grand

\footnotetext{
${ }^{8}$ See my 'How to Make Wagner Normal: Lohengrin's “tour de France” of 1891/92', Cambridge Opera Journal, 25/2 (2013), 121-137; and Yannick Simon, 'Lohengrin': un tour de France, 1887-1891 (Rennes, 2015).

${ }^{9}$ The standard narrative appears most explicitly in a biographical summary of 25 April 1907, prepared by the Association des Artistes Musiciens de la Ville de Lyon, transcribed in Anon. [Louis Bourgeois-Borgex] ed., Coup d'œil en arrière: Les premiers interprètes de Wagner en France. Louise Janssen (Lyon, [1926]), 55. Here Janssen is described as studying singing and opera in Graz with Materna before launching her career in France and as a rare example of a 'recognized Wagnerian singer' [consacrée cantatrice wagnérienne] (ibid.). However, Materna was in Graz in the 1860s, when Janssen was a small child, and seems to have returned there only briefly around 1894 at the end of a career based in Vienna - by which time Janssen had already created many of her Lyon roles. A further biographical article in this same volume, taken from the Journal des théatres, 1 February 1905, mentions a year's study with Materna after her creation of Eva (1896); however, this account is also riddled with inaccuracies (ibid., 48-50). Janssen undoubtedly studied with Materna in 1904, in Vienna (report in Le Salut public, 23 June 1904, 3).

${ }^{10}$ K. J. Kutsch and Leo Riemens, Grosses Sängerlexikon (updated edn., 7 vols.) (Munich, 2003), vol. 3, 2234.

${ }^{11}$ Felix Jahyer, Rosine Laborde (Paris, 1903), 14. I am grateful to Jean-Christophe Branger for alerting me to this pamphlet. See also Arthur Pougin's obituary on Laborde in Le Ménestrel, 7 September 1907, 288.
} 
opéra and the Italian dramatic repertoire who devoted herself to teaching, in Paris, from around 1865.

Neither is there a detectable early link with Wagner on the concert stage. Janssen had appeared in Paris in the years immediately preceding her Lyon début, including performances at the Société Nationale, singing Lieder and mélodie from at least 1888, at which period the purity of her singing voice was already a cause for comment. ${ }^{12}$ Her Scandinavian roots helped her become a natural agent of the Grieg awakening in Paris, and during these years she also sang Duparc and championed the songs of Charles Bordes. Returning to the song repertoire at the end of her career, she liked to programme Wagner's Wesendonck-Lieder, but there is no trace of her singing them, or even selected songs from the set, in the late 1880s; neither do we find her singing Wagnerian operatic extracts in concert during these early years. Yet, as her tombstone attests, from 1891 she premiered the vast majority of the available Wagnerian roles in Lyon and became indelibly associated with the city's Wagnerian progress. Her portfolio lacked only Brünnhilde's appearances in Die Walküre (she always sang Sieglinde) and in Siegfried. ${ }^{13}$ In Paris she was Siegrune in 1893 at the Paris premiere of Die Walküre (Opéra), one of Charles Lamoureux's three Isoldes in 1899 (Nouveau-Théâtre), and Gutrune in Alfred Cortot's Götterdämmerung of 1902 for the Société des Grandes Auditions (Théâtre du Château d'Eau). ${ }^{14}$

Pace later accounts of her début, Janssen did not take Lyon by storm on her arrival in 1891. As only the company's second-string 'Falcon' she was not heavily trailed in the press

\footnotetext{
${ }^{12}$ Léon Schlesinger in Le Ménestrel, 24 March 1889, 96.

${ }^{13}$ In addition, in Lyon a Senta would not be required until 1909, and Kundry remained impossible until 1914 under the Bayreuth Parsifal embargo. With the exception of concert extracts, she sang neither role.

${ }^{14}$ She does not have a dossier d'artiste at the Bibliothèque de l'Opéra.
} 
before her first appearance as Marguerite, which was in any case marred by intonation problems and nervous tension that strangled her top notes. ${ }^{15}$ Such problems had apparently disappeared by the time she sang Elsa (and indeed they would never recur). Here she quietly upstaged the Belgian tenor Nestor Massart in the title role, shaking the Lyonnais audience out of its celebrated reluctance to show enthusiasm. As the writer 'C.' in Le Nouvelliste put it, mentioning her first in his review of the cast: 'The public seems to have particularly enjoyed the very interesting interpreter of the role of Elsa, Mlle Janssen, a young Swede [sic] blessed with a voice of admirable timbre whose nuances and line she controls with real talent. She is a most poetic and touching Elsa. ${ }^{16}$ And if that evaluation seems somewhat distant from the stuff of operatic legend, it is worth recalling that in 1891 all the attention on Lohengrin in the French regions was political, given the necessity to ensure belated and orderly public acceptance of Wagner's work. Lyon was no exception, and the possibility that a new diva had landed was not apparently on the agenda.

Nevertheless, over the next two months the 1891 Lohengrin became a runaway success, dominating the Grand-Théâtre stage and necessitating numerous extra performances for which Janssen's artistry and stamina rendered her indispensable. This she well knew: a rare extant letter, addressed to Poncet and dated 2 April 1891, requests a large pay rise: 'As to the performances of Lohengrin that have been, or will be, given from 1 April to the end of the season, I trust you will be good enough to agree with me what I should be owed. I believe that, given the success of the work and the goodwill I have always been eager to show as a

\footnotetext{
15 'F. L.' [probably Francis Linossier] in Le Salut public, 28 January 1891, 2.

16 'Le public a paru goûter tout spécialement la très intéressante interprète du rôle d'Elsa, Mlle Janssen, une jeune Suédoise douée d'une voix admirablement timbrée et qu'elle nuance et conduit avec un réel talent. C'est une Elsa très poétique et très touchante.' 'C.', in Le Nouvelliste de Lyon, 27 February 1891, 2.
} 
member of the company, that it would be fair to allocate me 300 francs per performance. ${ }^{, 17}$ Poncet did not pay 300 francs, but he undoubtedly appreciated Janssen's box-office power as a Wagnerian. Between her first and second year with the company, he raised her basic pay from 800 to 1000 francs per month, while he increased her fee for individual performances from a mere 66 francs 65 centimes to 200 francs - specifically for performances of Tannhäuser. ${ }^{18}$ As the Lohengrin run of 1891 approached the end-of-season buffers, the critic Joseph Tardy began organising Lyon's operatic diary in a feature article pointedly titled 'After Lohengrin.' Here, he wrote, was an opportunity to show Paris the way: 'Having started so well, Lyon should cement its leading role in the decentralization of music. After the triumphal career of Lohengrin, we must not leap backwards. ${ }^{19}$ He urged Poncet as director not to retreat towards Derfliegende Höllander or to be content with Tannhäuser (which is what Poncet would ultimately choose), but to lobby more ambitiously for mounting Die

17 'Quant aux représentations de Lohengrin qui ont été ou seront données du premier avril à la fin de la saison, je vous prierai d'être assez aimable pour vous entendre avec moi, sur ce qui me sera dû. Je crois que, étant donné le succ[è]s de la pièce et la bonne volonté que je me suis toujours efforcé[e] de montrer comme pensionnaire, il serait juste de m'allouer trois cents francs par cachet.' Janssen to Poncet, 2 April 1891, private collection. Janssens' use of the masculine agreement for "efforcé" might be a slip - her orthography is irregular (she writes 'succès' as 'succés', for instance); but given the self-belief and business acumen exhibited in the letter, it might just as easily be deliberate.

${ }^{18}$ Arch. Mun. Lyon, 88 WP 051 and 88 WP 052, covering 1890 to 1892 . Janssen started out as the lowest-paid principal singer in the Lyon company (Arch. Mun. Lyon 88 WP 051, where her 800F per month basic salary compared starkly with that of the first tenor at 7000F). She was never paid at the level of a star singer; rather, from as early as 1891 she tended to broker a distinctive form of contract where she was paid per performance whenever she sang Wagner.

19 'Ayant aussi bien commencé, Lyon doit affirmer sa prépondérance dans la décentralisation musicale. Après la carrière triomphale de Lohengrin, on ne doit pas bondir en arrière.' J[oseph] Tardy, Le Salut public, 8 April $1891,2$. 
Meistersinger, whose orchestral and choral difficulty he acknowledged but of which he noted - as if it were the more compelling argument - that 'the only important female role (Eva) seems written for the pure voice and youthful charm of Mlle Janssen., 20

\section{Voice}

What then, was her appeal? In amplified form, certain of the descriptors from 'C's' lukewarm praise would become trademarks. They included the poetic and the touching (in part a reference to her acting ability), the special quality of her vocal timbre, and her phrasing. The latter quickly emerged as her secret weapon. An unsigned reviewer for Le Progrès de Lyon saw it from the start of her Wagnerian tenure, identifying 'especially at the ends of phrases, ineffable caresses and exquisite half-tints'; ${ }^{21}$ while at the first reprise of Lohengrin, in October 1891, the Salut public's Francis Linossier was moved to poetic prose by her technique, which he had already remarked on briefly in February: 'This artist is always interesting for the way she ends phrases. In a mere whisper of infinite delicacy, the voice tapers off as a light cloud of smoke dissipates in the air. ${ }^{22}$ The image of floating, upward motion is key. The technique came into its own in the later music dramas, where her Liebestod and the end of Götterdämmerung became signature scenes. (Her last known concert appearance, with Georges Witkowski’s Société des Grands Concerts in April 1913,

\footnotetext{
20 'le seul rôle féminin important (Eva) semble écrit exprès pour la voix si pure et le charme juvénile de Mlle Janssen.’ Ibid.

21 ،... surtout aux fins de phrase, d'ineffables caresses et d'exquises demi-teintes.' Unsigned, Le Progrès de Lyon, 28 February 1891, 3.

22 'C'est toujours par la façon dont cette artiste termine ses phrases qu'elle est intéressante; ce n'est qu'un susurement [sic] d'une délicatesse infinie, la voix s'éteint comme se dissipe dans l'air un léger nuage de fumée.' Francis L. in Le Salut public, 31 October 1891, 2.
} 
ended with Brünnhilde's Immolation Scene.) While no one to my knowledge explicitly related Janssen's technique to Wagner's increasing love of cadential avoidance and elision, it seems tailor-made to complement it. As a result, Janssen must have sounded perpetually longing and ecstatic, as though each uplifted phrase drew her and her audience to ever greater heights of emotion. And yet she created that sonorous intensity with an intimacy that traded on quiet dynamics, bringing her audience towards her rather than projecting her voice outwards at all times.

Indeed, she seems never to have needed to project with effort, or to the point of harshness. Nowhere is she referred to as a powerful singer. This was deliberate - a concealment of art with art. The best singer, she wrote in her essay of 1905, 'is the one who gives the illusion of not singing - at least of doing so effortlessly; the singer whose art does not appear to distract the listener; the singer who can freely vibrate and palpitate with the music, like the instrument in the hands of a virtuoso. ${ }^{, 23}$ For Janssen, a laser-like vocal timbre seems to have done the requisite work, enabling her to cut through the orchestra or float above it as necessary. In this vein an unsigned reviewer for Le Progrès de Lyon described her voice as 'of an exquisite and penetrating freshness; it resounds without weakness or tremulousness through the whole range of ravishing half-tints. ${ }^{24}$ Elsewhere, references to purity, liquid crystal, and radiance or brightness recur across the critical spectrum, with signs appearing only around 1906 (from Léon Vallas) that this element of her magnetism as a performer was finally beginning to weaken. Janssen's retirement from the stage shortly

\footnotetext{
23 'Le meilleur chanteur est celui qui donnerait l'illusion de ne pas chanter, au moins de le faire sans effort; celui dont l'art n'apparaîtrait pas pour distraire l'auditeur; celui qui pourrait librement vibrer et frissonner avec la musique, comme l'instrument dans la main d'un virtuose.' Louise Janssen, La Revue de Lyon, 9 April 1905, 293. 24 'L’organe est d'une fraîcheur exquise et pénétrante, il résonne sans faiblesse ni chevrottement dans toute l'étendue de demi-teintes ravissantes.' Unsigned, Lyon républicain, 27 February 1891, 3.
} 
afterwards, in 1907, suggests that she agreed; but even so, the legend of her voice as 'divine', 'exquisite', and 'incomparable' lingered in the face of all competition save for that of Félia Litvinne - to whom I shall return.

It is likely that this focus on timbre brought with it a concomitant sacrifice that maddened some critics while hardly bothering others: that her diction was indistinct. This was a separate question from that of her perpetual Danish accent in the singing of French. It was a matter of communication of local meaning within an operatic culture that had prized the literary aspects of opera for centuries and in which the pull of the diseuse as opposed to the cantatrice was being keenly felt in song and opera alike. ${ }^{25}$ Early critics, such as 'L.' in the Express de Lyon, deplored her soft-edged approach in print until they bored themselves into silence. ${ }^{26}$ Later critics observed the same but found themselves less vexed; once her operatic career was over, the problem was hardly mentioned, as though it had simply become part of a singing persona in which sonority and colour trumped clear enunciation.

Among the best witnesses to the combined effect of these vocal qualities is Léon Vallas, who moved from being a fervent supporter to an ambivalent one and finally a pugnacious opponent not of Janssen herself but of the manner in which her fan club displayed blinkered hostility to anyone who had the temerity to try to sing 'her' roles. Vallas was still a schoolboy at the time of Janssen's début season, but he followed her, enraptured, from 1897 , marking up his scores to record performances attended - in 1900 he went to hear her sing

\footnotetext{
${ }^{25}$ Katherine Bergeron, Voice Lessons: French mélodie in the Belle Époque (New York, 2010), esp. chapter 4 'L'art de dire, or Language in Performance', 183-254.

${ }^{26}$ See his estimation of Janssen's Elsa (L'Express de Lyon, 27 February 1891, 3), Sieglinde (6 January 1894, 3) where he complains of having to repeat himself, and Eva (1 January 1897, 3), where he theatrically breaks off discussion of Janssen so that he does not have to write anything disagreeable on New Year's Eve. 'L.' remains unidentified.
} 
Isolde eight times in the space of a month. ${ }^{27}$ From its inception in 1903 the pages of his own Revue musicale de Lyon detail his journey towards ambivalence and frustration, but nothing comes across so vividly as his radio script of 1950 devoted to his own experience of Janssen's Lyon career, which begins with his falling entirely under her spell and then recounts the moment of her demystification somewhere around the end of 1904, courtesy of his future wife, Paule de Lestang:

A Lyonnais singer who in the realm of concert music held a role comparable to that of Louise Janssen - this singer, who has the originality of also being a harpsichordist, sang me Act 1 of Lohengrin while accompanying herself at the piano. A great admirer of her colleague's voice but, as a specialist singer, keenly aware of mannerisms that might be called 'Jansseniste', she altered her own singing style and began, without a word, to imitate the pronunciation and the delicious accents, the adorable little breaths of Janssen, and to imitate them really so precisely and exactly that after half a minute I burst into laughter; my partner too. Thanks to her discreet imitation, for the first time in seven years of experience at the Grand-Théâtre, I had just witnessed the analytical but blinding revelation of the divine Janssen's vocal manner, of her technique. I was rather vexed at this belated discovery; by no means vexed in relation to the revealer witness that I gave her my name. Just now my wife and I began again, at a distance of more than fifty years, to exult retrospectively in the exquisite memory of Louise Janssen's golden voice and her characteristic delivery. ${ }^{28}$

\footnotetext{
${ }^{27}$ Léon Vallas's reminiscence in Le Salut public, 14 February 1920, 3, lists the specific dates as evidence of his fidelity.

28 'Une cantatrice lyonnaise qui, dans le domaine de la musique non théâtrale a tenu un rôle comparable à celui de Louise JANSSEN, cette cantatrice, qui a l'originalité d'être aussi claveciniste, me chantait en s'accompagnant au piano le premier acte de LOHENGRIN. Grande admiratrice de la voix de sa collègue, mais,
} 
I have found no reference to this anecdote elsewhere; it appears to be a reminiscence that Vallas had kept under wraps for decades, as though Janssenisme needed to be a closed chapter before he could release it. That closure had effectively taken place seven years earlier, with the death in 1943 of a Jansseniste with whom Vallas was on friendly terms: Antoine Sallès. It was he - national and local politician, critic of Le Salut public under the by-line J. Amaury, and chair of the Comité d'Hommage à Louise Janssen (1930s) and Les Amis de Louise Janssen (1940s) - who organized the commissioning from Louis Prost of a bronze monument in her honour in 1937, and whose last Jansseniste gesture was to fundraise for and oversee the Croix-Rousse tombstone of 1943 that marks her grave today.

\section{Stage presence}

Janssen was not just a voice: the visual became central to her impact. That she thought of herself as an actor first and foremost is clear from the title of her 1905 essay, 'L'Acteur lyrique'. Early reviews mention inexperience but potential in her acting as Elsa, ${ }^{29}$ with her

comme spécialiste du chant, très consciente des manières..... janssénistes, elle modifia sa propre façon de chanter et se mit, sans me le dire, à imiter la prononciation et les délicieux accents, les adorables soufflets de JANSSEN, à les imiter joliment de façon si précise, si exacte que, au bout d'une demi-minute, j'éclatais de rire; ma partenaire aussi: grâce à sa discrète imitation, je venais, pour la première fois en sept ans de pratique de Grand-Théâtre, d'avoir la révélation analytique mais éclatante de la manière vocale, de la technique, de la divine JANSSEN. De ma tardive découverte, je fus un peu vexé; je n'en ai pas voulu à la révélatrice, si peu même que je lui ai donné mon nom; tout à l'heure, ma femme et moi recommencions, à plus de cinquante ans de distance, à nous extasier rétrospectivement au souvenir exquis de la voix d'or de Louise JANSSEN et de son intonation typique.' Léon Vallas, script for Radio-Lyon, broadcast September 1950. Fonds Vallas, Bibliothèque de Lyon, MS 38b, feuillet 26.

${ }^{29}$ For example, Unsigned, Lyon républicain, 27 February 1891, 3, on her Elsa. 
Sieglinde of 1894 marking a new level of accomplishment. ${ }^{30}$ Thereafter, she was duly referred to as much as an 'actress' as a singer, also attracting the more classical description of 'tragédienne lyrique' - which is what appears on her tombstone and which was undoubtedly aided by her taste for flowing, Grecian costumes and her attention to the poses of classical sculpture. ${ }^{31}$ Hence her Brünnhilde of 1904 in Götterdämmerung inspired Sallès to comparison with the Winged Victory of Samothrace, ${ }^{32}$ while in a comparison of Janssen and Litvinne as Isolde, Edmond Locard found Janssen far superior in her manner of conveying the meaning and expression of the score, whether or not she was singing at the same time. Inviting the reader to reflect on her mime as the love potion begins its work, among other moments within Tristan, he opined: 'Mlle Janssen has reached a degree of absolute perfection in this constant concordance of gesture and theme. [...] such attention to transcribing through gesture the meaning of a composition written with Leitmotives cannot be bettered., ${ }^{33}$

Yet to several critics of the 1890s she appeared to lack energy onstage, as though trapped passively in her 'poetic' and 'touching' world - or even sleepwalking through it: Francis Linossier, critic for Le Salut public, referred to a detachment [nonchalance] in her 1891 Elsa that made her look 'truly comatose' [véritablement endormie]. ${ }^{34}$ Others, such as the Progrès de Lyon critic, found her possessed of 'dreamy and rather sorrowful grace’ [sa

\footnotetext{
30 'la comédienne nous a paru fort en progrès.' Unsigned, Le Progrès de Lyon, 5 January 1894, 3.

${ }^{31}$ That she had her own stock of costumes and guarded them closely is clear from her letter to Poncet on 2 April 1891, where she specified that in any new agreement over pay they should remain her property.

${ }^{32}$ Amaury [Antoine Sallès], Le Salut public, 14 January 1904, 3.

33 'Or Mlle Janssen est parvenue à un degré de perfection absolu dans cette concordance constante des gestes et des thèmes. $[\ldots]$ on ne peut pousser plus loin le souci de transcrire par le geste ce qui signifie une composition écrite dans le procédé thématique.' Edmond Locard, La Revue musicale de Lyon, 18 March 1906, 682. Locard was a university lawyer and criminologist later famous for pioneering work in forensic science.
}

${ }^{34}$ Le Salut public, 31 October 1891, 2. 
grâce rêveuse et un peu triste]. ${ }^{35}$ By the time of her Sieglinde in 1894, an unnamed writer for Lyon républicain could refer to her attempts to shake herself out of her 'habitual torpor' [torpeur habituelle] - including her unclear diction - but he still demanded more dramatic energy. ${ }^{36}$ Yet in 1896 an unsigned critic for Le Salut public turned the question of 'torpor' on its head and reiterated his view of 1894, that Janssen exhibited a 'poetic and touching charm in the guise of this enigmatic Sieglinde who submits, with a kind of supernatural fatalism, to the force of her destiny. ${ }^{37}$ All these comments, whether positive or negative, speak to a stage presence that prized beauty over energy, and whose enchantment was predicated on the creation of a sense of mystery or other-worldliness. From 1900, with her Isolde, ecstatic variations on this theme became ubiquitous among her supporters and turned into the most enduring aspect of her legacy.

Extant photographs and postcards, many of which are collected in a pamphlet prepared by Janssenistes in $1926,{ }^{38}$ bear out many of these perspectives even though they necessarily capture studied poses. Specifically, they are unusual among theatrical publicity materials for their sense of drama, their interiority, and their intensity of expression: Janssen's deep-set eyes are permanently shadowed, making her gaze appear searching if not visionary. She also creates immediacy via simplicity of costume (including a frequent lack of head-covering), a willingness to look beyond, rather than into, the camera, and via her foregrounding of the role rather than of herself as its performer (in one shot as Elsa she

\footnotetext{
${ }^{35}$ Unsigned, Le Progrès de Lyon, 28 February 1891, 3.

${ }^{36}$ Unsigned, Lyon républicain, 4 January 1894, cited in L. Bordex, ed., Coup d'œil en arriere: Les premiers interprètes de Wagner en France. Louise Janssen (Lyon, [1926]), 23.

37 'son charme poétique et touchant sous le forme de cette énigmatique Sieglinde qui subit, avec une sorte de fatalisme surnaturel, l'entraînement de sa destinée.' Unsigned, Le Salut public, 19 March 1896, 2.

${ }^{38}$ [Borgex] (ed.), Coup d'œil en arrière. Discussed below.
} 
actually covers her face completely). We also see more physical freedom than theatrical shots of this period commonly show. An image of Janssen as Isolde in Act 2 of Tristan bears comparison with Sallès's description of the Winged Victory of Samothrace. It is not that Janssen's arms are flexed back in the manner of an angel's wings, but that, by holding them half aloft, she creates the same effect with her costume. Simultaneously she steps towards the viewer, her dark, heavily shadowed eyes slightly uplifted and scouring the middle distance beyond the camera and to its right, in a visual complement to the longing she performed through her singing [Plate 1].

Plate 1 Louise Janssen as Isolde (Act 2), in [Louis Bourgeois-Borgex] ed., Coup d'œil en arrière: Les premiers interprètes de Wagner en France. Louise Janssen (Lyon, [1926]). Courtesy of the Bibliothèque Nationale de France.

Similarly unusual is a shot of her Brünnhilde in Act III of Götterdämmerung, in which she inclines her head and upper body, doubtless in contemplation of the lifeless Siegfried, and uses the 'wings' of a very similar costume as both a backcloth to her face and a shield of privacy that creates an intimate moment on a potentially large stage. We do not see very much of her face - just her profile and lowered eyes. And although we must imagine the focus of her gaze, the curved outline of her body draws our eye inexorably towards it, lying at her feet. The vulnerability of the human Brünnhilde, devoid of armour, helmet, and weapons, is palpable, but so is a sense of rapt stillness that goes beyond the need to pose for the camera [Plate 2]. 
Plate 2 Louise Janssen as Brünnhilde, Götterdämmerung (Act 3), in [Louis BourgeoisBorgex] ed., Coup d'œil en arrière: Les premiers interprètes de Wagner en France. Louise Janssen (Lyon, [1926]). Courtesy of the Bibliothèque Nationale de France.

As in the case of Janssen's vocal technique, it is Vallas who pricks the bubble of poetic mystery. He does so with another belated revelation that seems to have no previous journalistic life: that what Janssen's audiences saw through their opera glasses was not just her acting, but her struggle with myopia.

Her acting, devoid of all traditional convention, was no less seductive than her voice or her Danish delivery; even her serious short sight was an additional attraction, for her gaze, naturally lost, accentuated her delicious expression of the innocent victim when, in Act I of Lohengrin, she arrived on stage before the king's tribunal... ${ }^{39}$

The outward effect of her appearing onstage with uncorrected vision was, in short, both a limitation and an essential component of her allure. It underpinned judgments of her sleepwalking through performances as much as it bolstered the quasi-protective instincts of her fans. And it is in the borrowed voice of a Jansseniste that Vallas proceeds to assess the impact of a premiere he was too young to attend, claiming rather theatrically that with her Elsa the entire public was conquered instantly, that no one watching her - including Ortrud and Frédéric (the Telramund of the French version) - could possibly have doubted her innocence, that when she began to sing the spell was complete, and that by the end of the

\footnotetext{
39 'Son jeu, dépourvu de toute convention traditionnelle, n'était pas moins séduisant que sa voix ou son chant danois; même sa grave myopie était un attrait de plus, car son regard, naturellement perdu, accentuait sa délicieuse physionomie d'innocente victime quand, au premier acte de LOHENGRIN, elle arrivait en scène devant le Tribunal du roi....' Léon Vallas, script for Radio-Lyon. Fonds Vallas, Bibliothèque de Lyon, MS 38b, feuillet 26 .
} 
evening all the regulars at the Grand-Theatre were more or less in love with her.

'Janssenisme', he says, was born on 26 February 1891.

\section{Typecasting}

Short sight or no, until 1904 Janssen tended to play 'innocent' or 'victim' roles rather than feisty heroines, and her last new role, in America during the 1906-1907 season, repeated the pattern: Butterfly. Casting her as Sieglinde rather than Brünnhilde in Die Walküre was an indication, on the part of theatre director Poncet, that he thought Wotan's warlike eldest daughter demanded a different kind of singer. Nevertheless, in 1904 and 1905 she created three Lyon roles that demanded considerably more dramatic breadth than hitherto: the human Brünnhilde of Götterdammerung, the manipulative Korrigan queen, Ked, of Sylvio Lazzari's post-Arthurian drama Armor, and Vincent d'Indy's Vita, in L'Étranger - which was, in terms of plot, the closest Janssen ever came to playing Wagner's Senta. Paid-up Janssenistes such as Sallès seemed surprised by the extent to which she rose to the first of these challenges, writing that she

perhaps surpassed, in all aspects of the interpretation she offered us, the most favourable opinion of her talent that her earlier career had already inspired. In this crushing role she not only displayed extraordinary vocal resilience, dominating the orchestra's most formidable outbursts right to the end with not a single lapse of her consistently pure and penetrating sound; but also, the dramatic artist was just as good as the lyric one. [...] admirable in the tenderness and passionate abandon of her farewell to Siegfried in the closing tableau of the Prologue, in the fury and deep despair of Act 2, in the nobility and tragic grandeur of Act 3, she made truly 
memorable, through her warmth of singing and the intensity of her dramatic effect, this magnificent idealization of her heroine. ${ }^{40}$

Sallès was not alone: one critic, whose by-line in Lyon mondain was D. Masqué, also commented approvingly on the way Janssen was 'by turns loving and violent' [[t]our à tour amoureuse et violente], though unlike Sallès he placed Siegfried, played by Marius Verdier, at the top of the singer hierarchy of his review. ${ }^{41}$ At the end of this season Janssen left for Vienna to study the Brünnhilde of Siegfried (and Gluck's Armide) with Materna. ${ }^{42}$ The following season the role of Ked drew from Raoul Cinoh [pseud. Chion], the regular critic of Lyon républicain, a new register of vocabulary: now Janssen was 'wild, trembling with passion, tender and tragic' [Farouche, vibrante de passion, tendre et tragique]; Sallès described her characterization as full of 'passionate vigour' [vigueur passionné]. ${ }^{43}$ During these two seasons, in her early forties, she seemed to have reached a new level and with that in mind, it is not so surprising that she sought out Materna, as though she intended to complete the Ring operas in due course.

\footnotetext{
40 'a dépassé peut-être, par la composition qu'elle nous en a donnée à tous égards, l'opinion si avantageuse pourtant que nous avait inspirée de son talent, sa carrière antérieure. Elle n'a pas seulement fait preuve, dans ce rôle écrasant, d'une extraordinaire résistance vocale, dominant jusqu'au bout, sans une défaillance de son organe inaltérablement pur et pénétrant, les plus formidables explosions de l'orchestre. L'artiste dramatique ne l'a cédé en rien chez elle à l'artiste lyrique. [...] admirable de tendresse et d'abandon passionné dans ses adieux à Siegfried, au tableau final du prologue, de fureur et de désespoir douloureux au second acte, de noblesse et de grandeur tragique au dernier, elle a rendu véritablement saisissante, par la chaleur de ses accents et l'intensité de ses effets dramatiques, cette magnifique idéalisation de son héroïne.” Amaury [Sallès], Le Salut public, 14 April $1904,3$.

${ }^{41}$ D. Masqué, Lyon mondain: journal du high-life lyonnais, 16 January 1904, [3].

${ }^{42}$ News item in Le Salut public, 23 June 1904, 3. However, she was never cast in Siegfried.

${ }^{43}$ Lyon républicain and Le Salut public, 22 November 1905, cited in [Borgex] (ed.), Un Coup d'œil, 51 and 52.
} 
If so, she was to be disappointed on three counts: first, because 1905 brought no repeat of the Ring of 1904, returning her instead to Lohengrin, Tannhäuser, and Reyer's Sigurd; second, because by 1906 her voice had begun to fade; and third, because that same year brought the devastating competition of Félia Litvinne in her prime. The year 1906 was a turning point - the first in which Janssen experienced serious rivalry, which sparked complaints over the next six years from critics in Vallas's journal that the parti pris of her supporters made them both unfair to guest sopranos singing 'her' roles, and stuck in a Wagnerian rut. ${ }^{44}$ Able to see off Elise Kutschera de Nys in January 1906, amid noisy slanging-matches between Janssenistes and Kutcheristes after the latter's Lohengrin, Janssen could not survive comparison with Lyon's new guest soprano Litvinne, with whom she alternated appearances in her signature Wagnerian roles of Elsa, Isolde, and Brünnhilde in Götterdämmerung. Masqué's successor at Lyon mondain, A. Franchet, is probably the diplomatically unsigned author of a review of Tosca that noted of Litvinne, as though in passing, that in Tristan 'This wonderful actress is the incomparable, the ideal Wagnerian Isolde, that Mme Janssen could only let us glimpse. ${ }^{45}$

In the Revue musicale de Lyon it fell mostly to the Jansseniste Edmond Locard, who had judged his idol 'incomparable' opposite Verdier in her Wagnerian roles in 1905, to compare the three sopranos. His terms of reference returned Janssen to the dream-world of her pre-1904 roles. Kutschera, he opined, had been miscast as Elsa and as Elisabeth because in these roles 'the superiority of Mlle Louise Janssen is assured' [la supériorité de Mlle Louise Janssen s'affirme]; Götterdämmerung would have suited Kutschera better: 'All her

\footnotetext{
${ }^{44}$ See for example La Revue musicale de Lyon, 4 March 1906, 607 (Marc Mathieu), 22 March 1908, 673

(Vallas), 12 December 1912, 200 (unsigned, presumably Vallas).

45 'La merveilleuse actrice est incomparablement l'Isolde rêvée et wagnérienne que Mme Janssen ne nous a laissé qu'entrevoir.' Unsigned, Lyon mondain, 17 March 1906, [2].
} 
qualities - timbre and volume of the voice, physical robustness, gestural energy, are especially appropriate to Brunnhilde's strong character and not to the dreamy, ethereal, mystical psyche of Elsa or of saint Elisabeth. ${ }^{46}$ Litvinne, though, matched Janssen in some ways as Elsa, for where Janssen appeared more convincing in Act 1 where she portrayed Elsa as 'a mystical, inspired, transcendent and, all told, barely human figure', Litvinne showed more insight into the human emotion of the woman whose tragedy ended the opera. ${ }^{47}$ The two appeared complementary. Isolde, though, was the acid test. Setting aside the question of Janssen's vocal fatigue by Act 3 (on which Vallas and Locard agreed), Locard credited Litvinne with providing the more dignified heroine with a stronger, fuller voice, and Janssen the more passionate lover with a greater understanding of the psychology of the drama and unsurpassed in bringing together gesture and musical meaning. ${ }^{48} \mathrm{He}$ declared a (chivalrous) tie, although hindsight enables us to see how the necessity of the exercise, combined with his disappointment at Janssen's underwhelming Liebestod, might have brought it closer to a farewell.

Janssen's retirement from the Lyon stage seems to have been no more trumpeted than her arrival, though her absence the following season was loudly decried by the Janssenistes when Die Meistersinger returned belatedly to the Grand-Théâtre - its first run since the heady days of the French premiere. In March 1907 she returned from her American tour to sing Elisabeth to Verdier's Tannhäuser, her entrance greeted with a long ovation before she had

\footnotetext{
46 'Toutes ses qualités, timbre et volume de la voix, robustesse physique, énergie du jeu, conviennent très particulièrement au caractère marqué de Brunnhild, et non au psychisme rêveur, élhéré, mystique, d'Elsa ou de sainte Elisabeth.' Edmond Locard, La Revue musicale de Lyon, 14 January 1906, 412.

47 'une figure mystique, inspirée, transcendante, et, somme toute, peu humaine'. Edmond Locard, La Revue musicale de Lyon, 25 March 1906, 705-707.

${ }^{48}$ Edmond Locard, La Revue musicale de Lyon, 18 March 1906, 683.
} 
sung a single note. ${ }^{49}$ Thereafter she simply disappeared from the Grand-Théâtre's listings, switching all her attention to the kinds of concert activity - for charity and with local institutions such as Georges Witkowski’s Société des Grands Concerts - that she had previously mixed with her operatic endeavours. She returned to the song repertoire, especially Schumann and Grieg, and kept the Wagnerian flame alight with performances of the Wesendonck-Lieder and of selected scenes from the music dramas, notably the closing pages of Tristan and Götterdämmerung, in which, released from the cumulative tiredness of full stage presentation, she regained some of her old magic. Götterdämmerung seems to be the last music she sang at a public concert, the occasion being the centenary Wagner Festival of 1913 conducted by Witkowski, which saw her partnered, once more, by Verdier. Witkowski brought together his choir, the Schola Cantorum de Lyon, with his orchestra, the Société des Grands Concerts, to present a programme of extracts from Der fliegende Höllander, Tristan, Die Meistersinger, Parsifal, and Götterdämmerung. Sallès waxed lyrical about both soloists - Janssen the 'unforgettable creator of Wagner's output on our principal stage' and Verdier 'the most accomplished Wagner tenor one could dream of' ${ }^{50}$ Both excelled, but Janssen had the last word, ending the concert with Brünnhilde's immolation scene. Once more she simply evaporated: there was no benefit concert or grand farewell. Indeed, for around a decade starting with the War years she seems almost forgotten.

\section{Afterburn}

It took the untimely death of Verdier in 1925, and the decision to honour him with a large medallion in the foyer of the Grand-Théâtre, to rekindle Janssenisme in a new public form,

\footnotetext{
${ }^{49}$ Amaury [Sallès], Le Salut public, 16 March 1907, 2.

50 'l'inoubliable créatrice de l'œuvre wagnérienne sur notre première scène [...], le ténor wagnérien le plus accompli qu'on puisse rêver'. Amaury [Sallès], Le Salut public, 16 April 1913, 2.
} 
this time both tangible and monumental. First came a pamphlet of short essays, press cuttings, and photographs edited anonymously by the landscape painter and portraitist Louis Bourgeois-Borgex and compiled as a tribute; then concerts in Janssen's honour began to appear. Finally, the two monuments that still mark Lyon's enduring memory: a partner medallion by the Lyonnais sculptor Louis Prost commissioned by subscription and installed opposite that of Verdier in December 1937, shortly before her death; and the headstone of 1943, which was also paid for by subscription. Alongside Bourgeois-Borgex, whose tribute was published via the journal L'Express de Lyon, the Jansseniste mantle was retained by Sallès at Le Salut public in tandem with the conductor Henry Fellot.

The spirit of competition that seems to have catalysed the Bourgeois-Borgex pamphlet is readily mirrored in the pages of this latter newspaper, where the defence of Janssen's memory (despite the fact that she was still alive and teaching) dripped with nostalgia for a golden Wagnerian age that she and she alone had inaugurated. Mentioning the pamphlet, for which he gave no title or editor, as though it were initially intended as a private publication, Fellot used his regular feuilleton to dive into a panegyric all the more strikingly indulgent for its being pegged on something his readers could not readily identify, still less obtain. Like Locard in his comparison of Janssen and Litvinne in 1906 he reverted to the Janssen that her fans seem to have wanted preserved forever: the débutante and pupil of Materna - the 'charming young girl' [charmante jeune fille] who overturned all her audience's expectations about singing and stage movement:

Youth, poetry, tenderness, there you had everything about Louise Janssen, whether she incarnated Elsa, Elisabeth, Sieglinde, Isolde, or Eva, and it is impossible to avoid a deep sense of melancholy and pity when one evokes the unforgettable past now gone forever that this exquisite and noble artist, first alone, and then with the great 
Verdier, animated for so long with her physical grace, her harmonious movement, and, more importantly, the intensity and sincerity of her emotion. ${ }^{51}$

Erased from Fellot's record were her Brünnhilde, her Ked, and her Vita: these, implicitly, were not the real Janssen. And where Vallas complained in 1908 that Janssenistes conflated Lyon's Wagnerism and their favourite soprano, ${ }^{52}$ Fellot was selective even within the Wagnerian canon, rendering Janssen a femme fragile - a specialist in the portrayal of the 'eternal feminine' about which Maurice Maeterlinck had written in his chapter 'On Women' in his essay collection Le Trésor des humbles of $1896 .^{53}$

The pamphlet itself was more balanced, acknowledging via reviews or images all the roles she created in Lyon. Bourgeois-Borgex brought together carefully selected press cuttings from her premieres and a selection of concerts, ensuring that sources from all the major papers - Lyon républicain, Le Nouvelliste de Lyon, L'Express de Lyon, Le Progrès de Lyon, and Le Salut public - were represented to illustrate her broad support base.

Disadvantageous critical comparisons with other singers - notably from 'L.' in L'Express were excised; nothing from the Revue musicale de Lyon was included, and passages from other newspaper reviews were occasionally edited to give them more rhetorical weight. A long printed list of fans and well-wishers left out major supporters despite extending to 115

\footnotetext{
51 'Jeunesse, poésie, tendresse, ce fut là toute Louise Janssen, qu'elle incarnât Elsa, Elisabeth, Sieglinde, Yseult ou Eva, et nous ne pouvons nous défendre d'un profond sentiment de mélancolie et d'attendrissement, à évoquer ce passée inoubliable et à jamais disparu, que cette exquise et noble artiste, d'abord seule, puis avec le grand Verdier, à animé si longtemps de sa grâce physique, de sa plastique harmonieuse et, plus encore, de l'intensité èt de la sincérité de son émotion.’ Henry Fellot, Le Salut public, 2 October 1926, 2.

${ }^{52}$ Léon Vallas, La Revue musicale de Lyon, 22 March 1908, 672.

${ }^{53}$ For an excellent discussion, see Annegret Fauser, 'Lili Boulanger's "La princesse Maleine”: A Composer and Her Heroine as Literary Icons', Journal of the Royal Musical Association, 122/1 (1997), 68-108, esp. 84-5.
} 
names. An editor's introduction began a large-scale recapitulation, distillation, and intensification of the tributes of the previous three decades. Inevitably, the favoured subset of roles re-emerged. Bourgeois-Borgex sketched Janssen's Lyon career, focusing on the superhuman revelation of her Elsa, who 'seemed to have descended from a stained-glass window to sing of her love for Parsifal's son' [semblait être descendu d'un vitrail afin de chanter son amour pour le fils de Parsifal]. ${ }^{54}$ Two articles followed, probably newly written, contextualising her contribution as a decentralizing figure. There was unintended irony in ' $\mathrm{P}$. P.' writing on the crucial decentralist importance of her Die Meistersinger in 1896, since it was a work she sang for a single run. But that original production was the work's French premiere and had thereby shown Paris Lyon's mettle as an operatic capital. As he put it, in prose that satirized the overweening authority of Paris as compared with Lyon, 'Louise JANSSEN whose recent successes in Lohengrin, Tannhäuser, Die Walküre had consecrated her as a great artist for Lyonnais music lovers, was now discovered by the pontiffs. ${ }^{, 55}$ In Lyon, she had exercised what he termed a benign dictatorship [une dictature ... artistique indéniable mais bienfaisante] as well as serving a priestly function as the 'Initiator' [1'Initiatrice] of a generation into Wagnerian understanding. ${ }^{56}$ The unsigned 'Jansseniste' who follows, and who sounds suspiciously like Locard, gave an ecstatic account of her naturalness of gesture based on her observation of the visual arts, the expressivity of her face

\footnotetext{
${ }^{54}$ [Borgex] (ed.), Un coup d'œeil, 10.

55 'Louise JANSSEN que ses récents succès dans Lohengrin, Tannhäuser, La Walkyrie avaient consacrée grande artiste auprès des amateurs lyonnais, était découverte par les pontifes.' 'P. P.', in Bordex (ed.), Coup d'œil, 15. Its revival in 1908, the year after Janssen's retirement, had prompted ugly protests directed at 'her' replacement, Marguerite Claessens - which he did not mention. See the protest article by Léon Vallas in La Revue musicale de Lyon, 22 March 1908, 670-73.

56 'P. P.', in [Borgex] (ed.), Un Coup d'œil, 15.
} 
as a 'clear mirror where all the states of the soul crystallize...' [le clair miroir où se cristallisent les états d'âme...], and, in another decentralist gesture, her capacity to equal, in opera, the quality of Sarah Bernhardt in the theatre. ${ }^{57}$ The panegyric of the tribute pamphlet continued via an undated and unsigned poetic tribute to Janssen's dedication to Art and Beauty via her portrayal of 'The whole poem of women' [Tout le poème de la femme], but which (again) neglected to mention her Brünnhilde among her Wagnerian roles and instead foregrounded her Elsa, Elisabeth, and Sieglinde - starting with Elsa, the 'woman who is a victim because she is a woman, a victim of herself' [femme victime parce qu'elle est femme, victime d'elle-même]. ${ }^{58}$

What Janssen herself thought of such effusive tributes is difficult to say. During her operatic career she showed she could be as focused and strategic offstage as she appeared soft-edged when playing the roles her fans decided were her main claims to fame. Her practice of wining and dining composers and critics - including on one occasion whisking the entire critical fraternity to an impromptu concert at her house once her portion of a doublebill was done - does not suggest the shrinking violet her fans so loved to applaud. ${ }^{59}$

\footnotetext{
57 'Un Jansseniste', in [Borgex] (ed.), Un Coup d'œil, 18-19.

${ }^{58}$ Given in [Borgex] (ed.), Un Coup d'œil, 34.

${ }^{59}$ Vallas indicates that he knew Janssen somewhat through such social events: his papers at the Bibliothèque Municipale de Lyon include one invitation at which Janssen invites him to dine with her and Sylvio Lazzari, the composer of Armor, shortly before the Lyon premiere (postcard, Fonds Vallas MS 183 feuillet 3, 3 November 1905); and the collective capture of Lyon's critics on the night she first sang Vita in L'Étranger, also included the composer Vincent d'Indy (Vallas, radio script, Fonds Vallas MS 38b, feuillet 26). If Janssen's behaviour constituted elegant bribery, as might be supposed, it is a moot point whether it was selfish, altruistic (to help Lazzari and D'Indy), or both. It was certainly not unknown for musicians to bring as many critics 'inside the tent' as possible: when Georges-Martin Witkoswki set up his new choir, the Schola Cantorum de Lyon, in 1902 03, his inaugural committee included six critics representing five local papers. See Yves Ferraton, Cinquante
} 
Nevertheless she avoided polemic and special pleading alike. Given her status in Lyon she could have refused to sing in the traditional block 'début' performances at the beginning of each season, and yet we still find her taking her place in such ritual auditions as late as 1900 . Equally, when side-lined from the celebrations of 1926 to install the Verdier monument at the Grand-Théâtre - to the public consternation of her fans - she simply turned up in the audience, incognito, to pay her respects alongside everyone else. ${ }^{60}$

\section{The Janssen Myth: A Symbolist Soprano}

For all that the construction of Louise Janssen as a French Wagnerian diva is predicated on stereotypically male conceptions of the femme fragile, her Lyon career represents a brief window when Lyon possessed an analogue to the heady mix of classicism and medievalism so enthusiastically embraced by fin-de-siècle poets and artists, whether members of the Aesthetic and pre-Raphaelite movements in England or the Symbolists in France, and whether contributing explicitly to Wagner's afterlife or not. Janssen's softly-folded robes and classical poses, combined with her ecstatic lassitude and smoky eyes, recall the frescoes of the Lyonnais Puvis de Chavannes (one of which was already installed in the Musée des Beaux-Arts in Lyon by the mid-1880s) as much as the stained glass and medievalist portraiture of Burne-Jones and his predecessors in the pre-Raphaelite brotherhood.

The latter's creation of the image of the visionary ange-femme was already making its mark by the Paris Exposition Universelle of 1878, but its influence became pervasive in the

ans de vie musicale à Lyon (Trévoux, 1984), 65. None of this activity prevented negative reviews, though it may have resulted in some toning down of language.

${ }^{60}$ Henry Fellot, Le Salut public, 19 March 1927, 3. 
1890s. ${ }^{61}$ We might also note how the free-flowing hair of her Brünnhilde (Plate 2) combines with a costume which, in this shot at least, suggests a willowy androgyny also characteristic of pre-Raphaelite figures - it is part young knight with tunic and cape, and part flowing robe. In France the ange-femme becomes closely associated with Wagnerian afterlives in canvases such as the heavily medievalist Isolde paintings of Puvis de Chavannes' pupil, Gaston Bussière, who trained initially at Lyon's Académie des Beaux-Arts before working with Puvis de Chavannes himself in Paris. The undated Yseult la blonde (Plate 3), for instance, takes the smoky eyes and visionary gaze of English models from Holman Hunt's The Awakening Conscience of 1853, to the late Burne-Jones's Vespertina Quies of 1893, and suffuses them with the iridescence of stained glass - which was itself central to the art nouveau movement in fin-de-siecle Lyon. ${ }^{62}$ Symbolist artists such as Odilon Redon took such expressions of the Wagnerian gaze to further extremes, as in his 1890s drawings of Parsifal, where the eyes move beyond the visionary to become dark pools of oblivion.

Plate 3. Gaston Bussière (1862-1928), Yseult la blonde. Courtesy of the Musée des Ursulines, Mâcon.

As Langham Smith notes, in pre-Raphaelite images, 'outward stillness often conceals profound inner drama'; ${ }^{63}$ Leon Botstein refers, in related fashion, to their 'silence and

\footnotetext{
${ }^{61}$ Richard Langham Smith, 'Debussy and the Pre-Raphaelites', $19^{\text {th }}$-Century Music, 5/2 (1981), 95-109, at 9598.

${ }^{62}$ For discussions of the relationship between Lyon's stained-glass artisans, Louis-Comfort Tiffany and William Morris, see Amaz, Jacques et al (ed.), Lyon et le vitrail: d'un néo-médiéval à l'art nouveau (Les Dossiers des Archives Municipales, 3) (Lyon, 1992).

${ }^{63}$ Ibid., 97.
} 
stillness', and to 'a kind of visionary fatalism' that he associates with the dream world and the evocation of the supernatural. ${ }^{64}$ At the same time, Botstein detects a sense of remoteness and distance of both time and space: 'Depicted action is placed at an unreachable distance. The spiritual interior of the viewer becomes the subject of the image, as in a dream. ${ }^{65}$ Just as Janssen's onstage image chimed with that of the ange-femme in pre-Raphaelite and Symbolist paintings, so the critical vocabulary she inspired appears strikingly consonant with such descriptions of the distanced, dreamlike, and yet passionate interiority of pre-Raphaelite art. Allusions to stained-glass windows and mysticism, to languorous stage-presence, to an essential melancholy, are all germane to such a connection, even though no contemporary reviewer, to my knowledge, makes it explicit.

And yet an indirect connection does indeed emerge. It does so gradually courtesy of Debussy, about whom both Langham Smith and Botstein were writing in the above discussions of the pre-Raphaelites. Starting amid high Wagnerism and proceeding via rebuffs catalysed by the shock of the new, a link with Mélisande surfaces two decades later as nostalgia for what might have been. When Locard expatiates in 1906 on the qualities of Elsa's Act 1 character, he follows a description of the ange-femme with a move to darker territory:

In Act 1 she appears to us in a state of ecstasy, of autosuggestion, of vision, and, so to speak, of mystical hypnosis. Weak, lacking energy [...]. Incapable of defending herself, crushed by fear [...], she has renounced the idea of untangling the intrigue that binds her [...]. She has not even tried to understand the fatal sequence that saw her

\footnotetext{
${ }^{64}$ Leon Botstein, 'Beyond the Illusions of Realism: Painting and Debussy's Break with Tradition', in Debussy and his World, ed. Jane Fulcher (Princeton and Oxford, 2001), 141-79, at 169.

${ }^{65}$ Ibid., 169.
} 
accused of fratricide; she is beaten, conquered without a fight $[\ldots]$; she can do nothing for herself $[\ldots]$... And so, through that natural tendency of the weak to seek, beyond the possible, the help that they cannot find in the tangible and the real, Elsa takes refuge in the realm of dreams. ${ }^{66}$

The stillness here is not that of reverie, but of a passive victim locked (and lost) in a medieval nightmare. Maeterlinck - whether as essayist on women or playwright creating heroines springs immediately to mind, and Debussy with him. In 1906 there was no trigger for Locard to pursue a Debussyan analogy, whether positive or negative; the same was true the following year, when Sallès urged the Grand-Théâtre's directors Flon and Landouzy to be courageous and to experiment with the new repertory now succeeding in Paris: Russian opera, Salomé, and Pelléas. And in an echo of Joseph Tardy à propos Die Meistersinger in 1891, he pointed out, on the front page of Le Salut public, that in Louise Janssen and Alexandre Geyre, Lyon possessed 'the right singers to embody the heroes of this delicious legend'. ${ }^{67}$ In the event, Sallès was disappointed by Debussy's opera precisely because he found it too symbolist, its simplicity too studied [voulue], and its declamation spineless [invertebrée] and so childlike as to seem childish [puérile]. ${ }^{68}$ It paled musically in comparison with one of its inspirations,

66 'Elle nous apparaît, au premier acte, en état d'extase, d'autosuggestion, de vision, et pour ainsi parler, d'hypnose mystique. Faible, sans énergie, sans caractère [...]. Incapable de se défendre, écrasée par la peur du supplice qui la menace [...], elle a renoncé à démêler l'intrigue nouée autour d'elle [...]. Elle n'a même pas tenté de comprendre l'enchaînement de fatalité l'accusait si clairement du fratricide; elle est accablée, vaincue sans combat [...]; elle ne peut rien pour elle-même [...]. Et alors, par cette tendance naturelle des faibles à chercher, hors du possible, l'aide qu'ils ne savent pas trouver dans le tangible et le réel, Elsa se réfugie dans le rêve.' Edmond Locard, La Revue musicale de Lyon, 25 March 1906, 705-6.

67 ‘...les artistes qu'il faut pour incarner admirablement les héros de cette délicieuse légende’. Le Salut public, 5 June 1907, 1.

${ }^{68}$ Antoine Sallès, La Revue musicale de Lyon, 15 June 1908, 830. 
Mussorgsky's Boris, which Sallès had recently seen for the first time in Paris: Pelléas was a jewel, but a 'laboriously-carved' one [un joyau laborieusement ciselé]. Moreover, he claimed, 'In relation to Mussorgsky, Debussy, who is a sophisticate and a near-decadent, is what the English pre-Raphaelites are in relation to the painters of the primitive schools they claim to revive.' 69

Sallès, then, invoked the pre-Raphaelites disparagingly, and Debussy with them; yet this is the same Debussy for whom his heroine Janssen seems the ideal singer. He does not, to my knowledge, link these comments and ponder their internal tensions. Nevertheless, for the historian a counterfactual is irresistible in light of Lyon's recent history of Jansseniste opposition to new sopranos, and the proximity of the Pelléas premiere to the date of Janssen's retirement in 1907. For Janssen did not sing Mélisande: in 1908 when the Lyon premiere took place, Berthe César sang opposite Geyre's Pelléas. Had Janssen’s operatic career lasted one more season, would Debussy's opera have lasted more than its pitiful three Lyon performances, and would Sallès's estimation have been different had he seen his idol, as opposed to César, in the title role?

Had Janssen taken the role, we can also imagine how Vallas - Lyon's leading champion of Debussy - would likely have viewed the casting of a foreigner as an entirely natural extension of the work's performance history to date, and as a fitting way for Lyon to match Parisian practice. For when the New Zealand soprano Nora Long (stage name Nora d'Argel) was cast as Elsa in 1910 despite being too light a soprano, Vallas decided that her selling point had to be the exotic appeal of her accent:

\footnotetext{
69 'Debussy, qui est un raffiné et presque un décadent, est, par rapport à Moussorgsky ce que sont les préraphaélites anglais par rapport aux peintres des écoles primitives qu'ils prétendent ressusciter.' Antoine Sallès, La Revue musicale de Lyon, 15 June 1908, 828.
} 
Since the announcement of the revival of Lohengrin it had seemed strange that the light soprano Mlle d'Argel was cast in the role of Elsa; but I am not joking when I affirm that it is solely due to her English accent that this artist owes the weighty honour of singing a work that does not belong to her voice-type: the memory of Mlle Janssen's foreign accent, she having created the role in Lyon, has given us this bizarre casting. Equally, and for a similar reason, the main female role of Pelléas et Mélisande at the Opéra-Comique is reserved for English artists such as Mlle Maggie Teyte, ever since it was created by Mlle Mary Gardan $[\text { sic }]^{70}$

The idea of Janssen as Lyon's Mélisande manquée would endure; indeed it would, retrospectively, help to define her. Much of the rhetoric of her 'afterburn' makes sense in this context, as though her supporters were forever yearning for her to sublimate Wagner through Debussy, to be a familiar sonic guide through alien musical territory, and to provide them with another femme fragile for their collections of cherished operatic memories. Devoid of the stentorian or the overtly heroic, and accordingly rather distant from the general trajectory of Wagnerian singing, their preferred image of Janssen was predicated upon contradictions which we can read as closely related to the symbolist and art nouveau movements which surrounded them in Lyon itself: clarity and dreaminess, fragility and nobility, intensity and

\footnotetext{
70 'l'annonce de la reprise de Lohengrin, il avait paru étrange que l'on attribuât le rôle d'Elsa à Mlle-d'Argel, chanteuse légère; mais ce n'est pas une plaisanterie d'affirmer que c'est uniquement à son accent anglais que cette artiste a dû le redoutable honneur d"interpréter une oeuvre qui ne ressortit pas à son emploi: le souvenir de l'accent étranger de Mlle Janssen, créatrice du rôle à Lyon, nous a valu cette distribution bizarre. De même, et pour une semblable raison, le rôle féminin principal de Pelléas et Mélisande à l'Opéra-Comique est réservé à des artistes anglaises comme MIIe Maggie Teyte, depuis qu'il fut créé par Mlle Mary Gardan [Garden].' Léon Vallas, La Revue musicale de Lyon, 25 December 1910, 344. Brisacq refers to Grieg's setting of Ibsen's 'En Svane,' Op. 25.
} 
impassivity. Through selective remembrance, audience nostalgia created a powerful myth of Janssen as a Wagnerian diva who was ideal and yet utterly distinctive, and to whose mature career Lyon, and Lyon alone, could lay claim.

\section{Coda}

In an anecdote of 1931, the journalist, jazz critic, and theatre promoter Robert Brisacq - a future director of the famous chorégies at the ancient Roman theatre in Orange - brought together all the existing elements of the Janssen legend in a poetic evocation of pilgrimage. By his own account, Brisacq was as extreme a Jansseniste fan as it was possible to be. He was too young to have heard his idol sing; he had merely seen the stills of her playing Elsa, Eva, Elisabeth, and Isolde (yet again Brünnhilde is omitted from the list), and he had read the Lyon press extensively. His journey took him to Janssen's residence in the Croix-Rousse area of Lyon, up the hill that lies a little to the north of the opera house she had once inhabited, and which he compared to Montmartre rather than Bayreuth. He described the moment at which the 68-year-old Janssen opened her door:

[...] presenting her expressive face, which questions and offers itself to the decoder of enigmas; and her unforgettable eyes, which remember the swan - that of Grieg's song as much as that of the Wagnerian Swan-Knight; and her unique voice which, in addressing to you the simple words of an exquisite host, has an air of sweet regret at never having sung Mélisande. ${ }^{71}$

\footnotetext{
71 'son visage expressif offert, qui interroge et s'offre au déchiffreur d'énigmes; et ses yeux inoubliables, qui se souviennent du cygne, d'une mélodie d'Edward Grieg autant que du wagnérien Chevalier au Cygne; et sa voix unique qui, en vous disant de simples mots familiers d'hôtesse exquise, a l'air de regretter doucement de n'avoir pas chanté Mélisande.' Robert Brisacq, article in La Rampe reprinted in La Volonté, 28 July 1931, and Le Salut public, 4 August 1931, 5.
} 
After conversation and entreaties Janssen sings him some Schumann Lieder, accompanying herself at the piano - murmuring softly 'in a voice on the verge of tears and yet as though held in a smile' ${ }^{72}$ His pilgrimage complete, Brisacq weeps.

\section{CAPTIONS}

Plate 1 Louise Janssen as Isolde (Act 2), in [Louis Bourgeois-Borgex] (ed.), Coup d'œil en arrière: Les premiers interprètes de Wagner en France. Louise Janssen (Lyon: Imp. Express, [1926]). Courtesy of the Bibliothèque Nationale de France.

Plate 2 Louise Janssen as Brünnhilde, Götterdämmerung (Act 3), in [Louis BourgeoisBorgex] (ed.), Coup d'œeil en arrière: Les premiers interprètes de Wagner en France. Louise Janssen (Lyon: Imp. Express, [1926]). Courtesy of the Bibliothèque Nationale de France.

Plate 3 Gaston Bussière (1862-1928), Yseult la blonde. Courtesy of the Musée des Ursulines, Mâcon.

72 ،...la voix aux bords des larmes et pourtant comme suspendue au sourire'. Ibid. 